\title{
UPAYA MENINGKATKAN AKTIVITAS BELAJAR SISWA MELALUI PENERAPAN MODEL COOPERATIVE SCRIPT PADA PEMBELAJARAN IPS DI KELAS VIII.1 SMP NEGERI 1 GUNUNG TULEH KABUPATEN PASAMAN BARAT
}

\author{
Oleh: \\ Surtani \\ Dosen Jurusan Geografi Universitas Negeri Padang \\ Email: surtaniharahap@gmail.com
}

Penelitian ini bertujuan untuk meningkatkan aktivitas belajar siswa melalui penerapan model pembelajaran Cooperative Script pada mata pelajaran IPS di kelas VIII.1 SMP Negeri 1 Gunung Tuleh Kabupaten Pasaman. Jenis penelitian ini adalah Penelitian Tindakan Kelas (PTK). Teknik pengumpulan data adalah lembar observasi. Subjek penelitian adalah siswa kelas VIII.1 tahun pembelajaran 2016-2017 berjumlah 24 orang. Teknik analisis data secara deskriptif Kuantitatif. Tindakan dilakukan dalam dua siklus dimana setiap siklus memiliki empat tahapan yakni perencanaan, pelaksanaan, observasi, dan refleksi. Setiap siklus dilakukan dalam dua kali pertemuan. Hasil Penelitian meliputi: (1) Pada Siklus pertama rata-rata aktivitas belajar siswa dari keempat komponen yang diteliti diperoleh data sebesar 36,4\% (kategori kurang) pada siklus kedua rata-rata aktivitas belajar siswa mengalami peningkatan menjadi 64,6\% (kategori baik). terjadi peningkatan sebesar 28,2\%. (2) Pada siklus pertama aktivitas belajar tertinggi terdapat pada aspek menjawab, sedangkan aktivitas belajar terendah terdapat pada aspek bertanya dengan. Pada siklus kedua aktivitas belajar tertinggi masih terdapat pada aspek, dan aktivitas belajar terendah juga pada aspek bertanya. (3) Hipotesis yang diajukan tentang peningkatan aktivitas belajar siswa dapat dilakukan melalui model Cooperative Script pada mata pelajaran IPS Di Kelas VIII.1 semester Juli-Desember 2016 SMP Negeri 1 Gunung Tuleh dapat diterima.

Keyword: Limbah, Rumah Tangga

\section{PENDAHULUAN}

Undang-undang Dasar Negeri RI

1945 mengisyaratkan bahwa pendidikan nasional berfungsi mengembangkan kemampuan dan membentuk watak serta peradaban bangsa yang bermartabat dalam rangka mencerdaskan kehidupan bangsa. Tujuan pendidikan nasional tersebut untuk mengembangkan potensi peserta didik agar menjadi manusia yang beriman dan bertakwa kepada Tuhan Yang Maha Esa, berakhlak mulia, sehat, berilmu, cakap, kreatif, mandiri dan menjadi warga Negara yang demokratis serta bertanggung jawab. Untuk mengemban fungsi tersebut pemerintah menyelenggarakan suatu system pendidikan nasional sebagai mana tercantum dalam Undang-Undang Nomor 20 tahun 2003 tentang Pendidikan Nasional.

Sehubungan dengan hal di atas pendidikan nasional menjamin pemerataan kesempatan pendidikan, peningkatan mutu dan relevansi serta efisiensi manajemen pendidikan. Pemerataan kesempatan 
pendidikan diwujudkan dalam program wajib belajar 9 tahun. Peningkatan mutu pendidikan diarahkan untuk meningkatkan kualitas manusia Indonesia seutuhnya melalui olah hati, olah pikir, olah rasa dan olah raga agar memiliki daya saing dalam menghadapi tantangan global. Peningkatan relevansi pendidikan dimaksudkan untuk menghasilkan lulusan yang sesuai dengan tuntutan kebutuhan berbasis potensi sumber daya manusia.

Peningkatan efesiensi manajemen pendidikan dilakukan penerapan manajemen berbasis sekolah dan pembaharuan pengelolaan pendidikan secara terencana, terarah dan berkesinambungan. Pembaharuan pendidikan pada dasarnya memiliki 3 unsur, yaitu 1) pembaharuan kuri kulum menyangkut materi yang akan diajarkan 2) peningkatan kualitas proses pembelajaran bagaimana materi diberikan 3) efektifitas metode pembelajaran. Pembaharuan kurikulum yang sedang dikembangkan, peningkatan kualitas pembelajaran dilakukan dengan mengembangkan berbagai paradigm dan pendekatan, efektifitas pembelajaran dikemas dengan kolaborasi metoda yang telah ada sebelumnya dengan metoda baru (Iryasman, 2006:10).

Guru sebagai komponen utama dalam proses pembelajaran harus mampu memahami hakikat materi pembelajaran. Untuk mengembangkan kemampuan berfikir siswa dan memahami model pembelajaran yang dapat merangsang kemampuan siswa untuk belajar. Disamping itu untuk mengembangkan potensi yang dimiliki untuk menjadi manusia cerdas, rasional, tidak emosional, kreatif, disiplin, mandiri, dan memiliki keterampilan yang mampu untuk memecahkan setiap permasalahan dalam kehidupannya terutama dalam belajar. Dengan pemecahan yang matang diharapkan aktivis belajar siswa meningkat.

Kenyataan di lapangan selama ini aktivitas belajar siswa masih rendah yang ditandai dengan nilai mata pelajaran IPS di kelas VIII.1 masih banyak yang berada di bawah KKM bahkan mencapai angka 19,4\% dari keseluruhan siswa. Fenomena ini diduga keras berkaitan dengan rendahnya aktivitas siswa dalam pembelajaran IPS.

Berdasarkan data yang ada nilai mata pelajaran IPS tahun ajaran 2015/2016 pada semester II diseluruh kelas VIII.1 SMP Negeri 1 Gunung Tuleh Kabupaten Pasaman Barat terangkum dalam tabel berikut ini:

Jumah Siswa yang belum tuntas pada UTS Semester Jan/Jun 2016 Mata Pelajaran IPS di Kelas VIII SMP N 1 Gunung Tuleh Kabupaten Pasaman Barat

Tabel 1.Persentase siswa belum tuntas

\begin{tabular}{|c|c|c|c|c|}
\hline No & Kelas & Siswa & KKM & $(\%)$ \\
\hline 1 & VIII.1 & 36 & 78 & 29 \\
\hline 2 & VIII.2 & 36 & 78 & 26 \\
\hline 3 & VIII.3 & 36 & 78 & 21 \\
\hline
\end{tabular}

Sumber: TU SMP Negeri 1 Gunung Tuleh

Dari tabel 1 di atas tergambar bahwa nilai UTS semester genap 2016 pada mata pelajaran IPS di kelas VIII.1 SMP Negeri 1 Gunung Tuleh Kabupaten Pasaman Barat masih rendah, karena masih banyak siswa yang hasil belajarnya belum mencapai KKM yang ditetapkan sekolah.

\section{Masalah}

Hasil renungan dan diskusi dengan teman sejawat permasalahan dalam penelitian ini adalah rendahnya aktivitas belajar siswa pada mata pelajaran IPS yang 
dilihat dari rendahnya hasil belajar siswa yang masih banyak dibawah KKM.

\section{Pemecahan Masalah}

Jalan keluar yang direncanakan adalah dengan menggunakan model pembelajaran Cooperative Script, model pembelajaran ini dapat melibatkan peserta didik secara aktif dalam pembelajaran. Pada Mata Pelajaran IPS Di Kelas VIII.1 SMP Negeri 1 Gunung Tuleh Kabupaten Pasaman Barat.

\section{TINJAUAN PUSTAKA}

\section{Aktivitas Belajar}

Aktivitas belajar merupakan bagian terpenting dari proses belajar karena aktivitas belajar adalah suatu kegiatan siswa selama proses pembelajaran berlangsung. Tanpa aktivitas tidak mungkin siswa dikatakan belajar. Menurut Sardiman (2005:101) tidak ada belajar kalau tidak ada aktivitas. Aktivitas merupakan prinsip yang sangat penting dalam interaksi belajar mengajar. Menurut Fobel dalam Sardiman (2005:101) bahwa anak itu harus berfikir dan bekerja sendiri. Dari kutipan diatas dapat diketahui yang lebih banyak melakukan aktivitas adalah anak itu sendiri, sedangkan guru hanya memberikan bimbingan dan arahan serta merencanakan segala kegiatan yang akan dikerjakan siswa. Aktivitas siswa tidak cukup hanya dengan mendengar atau mencatat saj tetapi lebih bersifat fisik atau mental.

Menurut Sudjana (1991:3) bahwa aktivitas siswa mencakup dua hal yang tidak dapat dipisahkan yakni aktivitas mental (emosional-intelektual) dan aktivitas motorik (gerak fisik). Kedua aspek tersebutberkaitan satu sama lain, saling mengisi dan membutuhkan. Oleh sebab itu kita keliru berpendapat bahwa optimalnya cara belajar siswa dilihat dari gerakan motorik dan atau dari gerakan mental semata-mata.

Berdasarkan pendapat di atas, jelaslah dalam proses pembelajaran, guru harus menggunakan strategi pembelajarannya yang dapat menghimpun aspek- aspek tersebut dalam suatu kegiatan pembelajaran yang terpadu melalui aspekaspek tersebut dalam suatu proses pembelajaran yang terpadu. Melalui kegiatan nyata yang harus dilaksanakan siswa dalam pembelajaran.

Paul B. Diedirch dalam Sardiman (2005:101) daftar yang berisi 177 macam kegiatan yang antara lain dapat digolongkan sebagai berikut: 1) Visual Aktivities yaitu membaca, memperhatikan gambar demonstrasi, percobaan pekerja orang lain. 2) Oral Aktivities yaitu mengatakan, merumuskan, bertanya, memberi sran, mengeluarkan pendapat, mengadakan wawancara, diskusi. 3) Listening Aktivities yaitu menulis cerita, laporan angket dan menyalin, 4) Drawing Aktivities yaitu menggambar membuat grafik, peta, diagram, membuat reparasi bermain, berkebun dan berternak, 5) Mental Ktivities yaitu mengigat menanggapi, memecahkan soal, menganalisis melihat hubungan dan mengambil keputusan, 5) Emotional Aktivities yaitu menarik minat, merasa bosan, gembira, bersemangat, bergairah, berani, tenang dan gugup.

Aktivitas jasmani dan rohani keduaduanya harus dihubungkan. Menurut Suryono (1992:75) keaktifan jasmani dan rohani itu antara lain: 1) Keaktivan indera 
yaitu pendengaran, penglihatan, peraba, dan lain-lain. 2) Keaktivan akal yaitu menimbang-nimbang, menyusun pendapat dan mengambil keputusan. 3) Keaktivan ingatan yaitu siswa menerima bahan pengajaran dan menyimpannya dalam otak, dan pada suatu saat Ia mampu untuk mengutarakan kembali. 4) Keaktivan emosi yaitu siswa hendaklah senantiasa mencintai pelajarannya. Jadi, dalam setiap pelajaran guru hendaknya mengusahakan siswa agar siswa dapat aktiv jasmani maupun rohaninya.

\section{Model Pembelajaran Cooperative Script}

Pembelajaran Coopertive Script merupakan pembelajaran yang terdiri dari kelompok kecil yang beranggotakan antara 4-5 orang. Setiap anggota saling membantu dan saling bekerja sama dalam membahas materi yang diberikan oleh guru namun tidak semua kerja sama kelompok dikatakan pembelajaran kooperatif.

Menurut Sereu dalam Depdiknas (2005:23) Pembelajaran Cooperative Script merupakan model pembelajran dimana siswa bekerja secara kelompok dan bergantian secara lisan mengikhtisarkan bagian-bagian materi yang dipelajari.

Pembelajaran Cooperative Script adalah pembelajaran yang menugaskan siswa untuk membaca dan membuat ringkasan atau ikhtisar materi yang dibaca. Langkah-langkah pembelajaran Cooperative Script (Depdiknas 2005:23) : 1) Guru membentuk siswa berkelompok yang aggotanya 4-5 orang. 2) Guru memenginformasikan materi untuk di baca dan membuat ringkasan 3) Guru menetapkan siapa yang pertama siapa yang berperan sebagai pembicara dan pendengar.
4) Pembicara membacakan ringkasannya selengkap mungkin dan memasukan ide-ide pokok dalam ringkasan, selanjutnya mempersentasekan di depan kelas.

Sementara pendengar: 1) Menyimak, mengoreksi, menunjukan ide-ide pokok yang kurang lengkap 2) Membantu mengingat atau menghapal ide-ide pokok dan menggabungkan dengan materi sebelumnya atau materi lain.

1) Bertukar peran semula sebagai pembicara ditukar sebagai pendengar atau sebaliknya.

2) Kesimpulan guru.

3) Penutup

Dalam merumuskan ringkasan terjadi perbedaan pendapat antara siswa yang membawa kelas dalam suasana diskusi, yang selanjutnya terjadi tanggung jawab. Melalui pertanyaan siswa didorong untuk menemukan jawaban dengan rumusan yang baik dan benar. Tanya jawab dalam diskusi dapat membantu siswa menumbuhkan perhatian dalam pelajaran serta menumbuhkan perhatian dan pengalamannya sehingga menghasilkan pengetahuan yang benar-benar bermakna.

\section{METODE PENELITIAN}

Jenis penelitian ini adalah Penelitian Tindakan Kelas yang dikembangkan oleh Chemmis dan Mc.Taggart (1993) yakni metode siklus yang terdiri dari : planning (perencanaan), acting (pelaksanan), observing (observasi), reflecting (refleksi). Keempat tahap ini merupakan satu siklus, yaitu satu putaran kegiatan yang beruntun dari tahap penyusunan rancangan sampai pada tahap refleksi. Apabila kriteria yang ditetapkan oleh peneliti sudah tercapai pada 
siklus pertama maka siklus berikutnya tidak dilanjutkan. Penelitian Tindakan Kelas ini dilaksanakan di kelas VIII.1 SMP Negeri 1 Gunung Tuleh Kabupaten Pasaman Barat. Penelitian ini menggunakan model pembelajaran Cooperative Script dengan tujuan untuk memperbaiki dan meningkatkan mutu pembelajaran di dalam kelas. Penelitian ini dilakukan di SMP Negeri 1 Gunung Tuleh Kabupaten Pasaman Barat di kelas VIII.1, dimana subjek (siswa) sebanyak 24 orang pada semester JuliDesember 2016 TP 2016/2017.

Teknik pengumpulan data yaitu Observasi dan alat pengumpul data lembaran observasi. Dalam penelitian ini data dianalisis secara deskriptif kuantitatif dengan menggunakan format presentase sebagai berikut:

Ket: $P=$ persentase

$$
P=\frac{F}{n} \times 100 \%
$$

Tabel 2. Rekapitulasi Aktivitas Siswa Belajar Siswa Pada Siklus Pertama

\begin{tabular}{|c|l|c|c|c|c|c|}
\hline \multirow{2}{*}{$\begin{array}{c}\text { N } \\
\text { o }\end{array}$} & \multirow{2}{*}{$\begin{array}{c}\text { Aktivitas } \\
\text { Siswa }\end{array}$} & \multicolumn{4}{|c|}{ Pertemuan } & \multirow{2}{*}{\begin{tabular}{c} 
Rata \\
-rata \\
\cline { 3 - 7 }
\end{tabular}} \\
\cline { 3 - 7 } & \multicolumn{2}{|c|}{1} & \multicolumn{2}{|c|}{2} & F \\
\cline { 3 - 7 } & Bertanya & 6 & 25 & 8 & 33,3 & 29,2 \\
\hline 2 & Menjawab & 11 & 45,8 & 12 & 50 & 47,9 \\
\hline 3 & Menyanggah & 6 & 25 & 9 & 37,5 & 31,2 \\
\hline 4 & Menyimpulkan & 8 & 33,3 & 10 & 41,6 & 37,5 \\
\hline & Rata-rata & & 32,3 & & 40,6 & 36,4 \\
\hline
\end{tabular}

Sumber : Pengolahan data primer 2016

Berdasarkan tabel di atas dari empat komponen aktivitas belajar siswa yang diamati pada siklus pertama dijabarkan sebagai berikut. Rata-rata aktivitas bertanya sebesar 29,2\%, Rata-rata aktivitas menjawab sebesar 47,9\%, Rata-rata aktivitas menyanggah sebesar $31,2 \%$, dan Rata-rata

$$
\begin{array}{ll}
F & =\text { frekuensi } \\
n & =\text { sampel } \\
100 \% & =\text { konstanta }
\end{array}
$$

\section{HASIL DAN PEMBAHASAN}

Pada bagian ini diuraikan tentang hasil penelitian dan pembahasan hasil penelitian siklus pertama dan siklus kedua yang telah dilakukan. Data diperoleh sesuai dengan instrumen yang digunakan yaitu hasil lembar observasi dan hasil belajar siswa.

\section{Siklus Pertama}

Berdasarkan tindakan yang dilakukan pada penelitian ini yakni "Meningkatkan Aktivitas Belajar Siswa pada Pembelajaran IPS" maka ada beberapa aspek yang akan diobservasi meliputi, , bertanya, menjawab, menyanggah dan menyimpulkan. Hasil penelitian siklus I tergambar pada tabel dibawah ini: aktivitas menyimpulkan sebesar 37,5\%. Rata-rata aktivitas tertinggi terdapat pada aspek menjawab yakni sebesar 47,9\%, sedangkan rata-rata aktivitas terendah terdapat pada aspek bertanya yaitu sebesar $29,2 \%$. rata-rata aktivitas belajar siswa pada 
siklus pertama sebesar $36,4 \%$ berada pada interval dan kategori kurang.

Dari hasil observasi aktivitas belajar siswa pada siklus pertama dapat dilihat aktivitas setiap pertemuan mengalami peningkatan namun belum mencapai target yang ditentukan yaitu $60 \%$, maka penelitian perlu dilanjutkan pada siklus berikutnya (siklus II).

\section{Siklus 2}

Pada siklus I belum ada aktivitas belajar siswa yang mencapai indikator keberhasilan yang ditetapkan, sehingga perlu ditingkatkan lagi pemahaman siswa dalam melaksanakan pembelajaran menggunakan model pembelajaran Cooperative Script yang nantinya dapat meningkatkan aktivitas belajar siswa. Untuk itu dilakukanlah siklus II. Data mengenai aktivitas siswa selama proses pembelajaran pada siklus kedua dapat dilihat pada Tabel berikut ini:

Tabel 3Rekapitulasi Aktivitas Siswa Belajar Siswa Pada Siklus Kedua

\begin{tabular}{|c|c|c|c|c|c|c|}
\hline \multirow{2}{*}{$\begin{array}{c}\text { N } \\
\text { o }\end{array}$} & \multirow{2}{*}{ Aktivitas } & \multicolumn{4}{|c|}{ Pertemuan } & \multirow{2}{*}{$\begin{array}{c}\text { Rata } \\
\text { Siswa }\end{array}$} \\
\cline { 3 - 6 } & & \multicolumn{2}{|c|}{1} & \multicolumn{2}{|c|}{2} & \\
\cline { 3 - 6 } & & $\mathrm{F}$ & $\%$ & $\mathrm{~F}$ & $\%$ & $(\%)$ \\
\hline 1 & Bertanya & 12 & 50 & 16 & 66,7 & 56,3 \\
\hline 2 & Menjawab & 16 & 66,7 & 20 & 83,3 & 74,9 \\
\hline 3 & Menyanggah & 13 & 54,1 & 15 & 62,5 & 60,3 \\
\hline 4 & Menyimpulkan & 14 & 58,3 & 18 & 75 & 66,6 \\
\hline & Rata-rata & & 57,2 & & 71,8 & 64,6 \\
\hline
\end{tabular}

Sumber : Pengolahan data primer 2016

Berdasarkan tabel di atas dari empat komponen aktivitas belajar siswa yang diamati pada siklus kedua dijabarkan sebagai berikut. Rata-rata aktivitas bertanya sebesar 56,3\%, Rata-rata aktivitas menjawab sebesar 74,9\%, Rata-rata aktivitas menyanggah sebesar $60,3 \%$, dan Rata-rata aktivitas menyimpulkan sebesar $66,6 \%$. Rata-rata aktivitas tertinggi terdapat pada aspek menjawab yakni sebesar 74,9\%, sedangkan rata-rata aktivitas terendah terdapat pada aspek bertanya yaitu sebesar $56,3 \%$. rata-rata aktivitas belajar siswa pada siklus kedua sebesar $64,6 \%$ berada pada interval dan kategori baik.

Selanjutnya dilakukan perbandingan rata-rata aktivitas belajar siswa dari siklus pertama ke siklus kedua tergambar pada tabel dibawah ini.

Tabel 4 Perbandingan Aktivitas Belajar Siswa Siklus Pertama dengan Siklus Kedua

\begin{tabular}{|c|c|c|c|c|}
\hline \multirow{2}{*}{$\begin{array}{l}\mathrm{N} \\
\mathrm{o}\end{array}$} & \multirow{2}{*}{$\begin{array}{l}\text { Aktivitas } \\
\text { Siswa }\end{array}$} & \multicolumn{2}{|c|}{ Rata-rata $(\%)$} & \multirow{2}{*}{$\begin{array}{l}\text { Peningk } \\
\text { atan } \\
\%\end{array}$} \\
\hline & & $\begin{array}{l}\text { Siklus } \\
\text { I }\end{array}$ & $\begin{array}{l}\text { Siklus } \\
\text { II }\end{array}$ & \\
\hline 1 & Bertanya & 29,2 & 56,3 & 27,1 \\
\hline 2 & Menjawab & 47,9 & 74,9 & 27 \\
\hline 3 & Menyanggah & 31,2 & 60,3 & 29,1 \\
\hline 4 & $\begin{array}{l}\text { Menyimpulka } \\
\mathrm{n}\end{array}$ & 37,5 & 66,6 & 29,1 \\
\hline & Rata-rata & 36,4 & 64,6 & 28,2 \\
\hline
\end{tabular}

Sumber: pengolahan data primer 2015

Perbandingan aktivitas belajar siswa siklus pertama dan siklus kedua yang dapat dilihat pada tabel di atas, semua motivasi siswa yang diamati menunjukkan 
peningkatan yaitu untuk aktivitas bertanya pada siklus pertama sebesar 29,2\% meningkat pada siklus kedua menjadi $56,3 \%$ yang berarti terjadi peningkatan sebesar $27,1 \%$. Terjadinya peningkatan pada aktivitas menjawab yaitu pada siklus pertama sebesar 47,9\% meningkat pada siklus kedua menjadi 74,9\% yang berarti terjadi peninngkatan sebesar $27 \%$. Peningkatan pada aktivitas menyanggah pada siklus pertama yaitu $31,2 \%$ dan meningkat pada siklus kedua menjadi $60,3 \%$ yang berarti terjadi peningkatan sebesar 29,1\%. Peningkatan pada aktivitas menyimpulkan yaitu pada siklus pertama sebesar 37,5\% meningkat pada siklus kedua menjadi $66,6 \%$ yang berarti terjadi peningkatan sebesar $29,1 \%$. rata-rata peningkatan motivasi belajar siswa dari siklus pertama ke siklus kedua sebesar $28,2 \%$.

Pada tahap siklus kedua ini mengalami peningkatan aktivitas siswa yang luar biasa, dan juga rata-rata aktivitas belajar siswa sudah berada besar dari $60 \%$ yaitu rata-rata aktivitas belajar siswa pada siklus ke II sebesa $64,4 \%$ dengan kategori baik. sehingga penelitian ini berakhir di siklus ke II.

\section{SIMPULAN}

Berdasarkan rumusan masalah, analisis data dan pembahasan hasil analisis tentang pengaruh model pelajaran Cooperative Script terhadap aktivitas belajar siswa pada mata pelajaran IPS Di Kelas VIII.1 semester Juli-Desember 2016 SMP Negeri 1 Gunung Tuleh dapat disimpulkan sebagai berikut:

Pada Siklus pertama rata-rata aktivitas belajar siswa dari keempat komponen yang diteliti diperoleh data sebesar 36,4\% (kategori kurang) pada siklus kedua rata-rata aktivitas belajar siswa mengalami peningkatan menjadi $64,6 \%$ (kategori baik). terjadi peningkatan sebesar $28,2 \%$.

Pada siklus pertama aktivitas belajar tertinggi terdapat pada aspek menjawab, sedangkan aktivitas belajar terendah terdapat pada aspek bertanya dengan. Pada siklus kedua aktivitas belajar tertinggi masih terdapat pada aspek, dan aktivitas belajar terendah juga pada aspek bertanya.

Hipotesis yang diajukan tentang peningkatan aktivitas belajar siswa dapat dilakukan melalui model Cooperative Script pada mata pelajaran IPS Di Kelas VIII.1 semester Juli-Desember 2016 SMP Negeri 1 Gunung Tuleh dapat diterima

\section{DAFTAR PUSTAKA}

Ahmadi, Abu dan Widodo. 1991. Psikologi Belajar. Jakarta: PT. Rineka cipta.

Chemmis and MC Taggart. 1988. Action Research Planner. Australia: Daikin University Liza. 2008. Belajar dan Game, Kurangi Kebosanan Siswa di Kelas. http://talkingstik. com.pembelajaran inovatif

Depdiknas. 2005. Strategi dan model pembelajaran. Jakarta: PT. Gramedia Utama

Sardiman.2005.Psikologi Belajar. Jakarta: PT. Gramedia

Sudjana, Nana.1991. Model-model Belajar CBSA. Bandung: Sinar Baru Algesindo Suryono.1992. Teknik Belajar Mengajar Dalam CBSA. Bandung: Sinar Baru Algesindo 